Article

\title{
Comparison of Sentinel-2 and High-Resolution Imagery for Mapping Land Abandonment in Fragmented Areas
}

\author{
Sergio Morell-Monzó ${ }^{1, *}$, Javier Estornell ${ }^{2}\left[\right.$ and María-Teresa Sebastiá-Frasquet ${ }^{1}(\mathbb{C}$ \\ 1 Instituto de Investigación para la Gestión Integrada de Zonas Costeras, Universitat Politècnica de València, \\ C/ Paraninfo, 1, 46730 Grau de Gandia, Spain; mtsebastia@hma.upv.es \\ 2 Geo-Environmental Cartography and Remote Sensing Group, Universitat Politècnica de València, \\ Camí de Vera s/n, 46022 Valencia, Espana; jaescre@upv.es \\ * Correspondence: sermomon@doctor.upv.es
}

Received: 22 May 2020; Accepted: 24 June 2020; Published: 26 June 2020

\begin{abstract}
Agricultural land abandonment is an important environmental issue in Europe. The proper management of agricultural areas has important implications for ecosystem services (food production, biodiversity, climate regulation and the landscape). In the coming years, an increase of abandoned areas is expected due to socio-economic changes. The identification and quantification of abandoned agricultural plots is key for monitoring this process and for applying management measures. The Valencian Region (Spain) is an important fruit and vegetable producing area in Europe, and it has the most important citrus industry. However, this agricultural sector is highly threatened by diverse factors, which have accelerated land abandonment. Landsat and MODIS satellite images have been used to map land abandonment. However, these images do not give good results in areas with high spatial fragmentation and small-sized agricultural plots. Sentinel-2 and airborne imagery shows unexplored potential to overcome this thanks to higher spatial resolutions. In this work, three models were compared for mapping abandoned plots using Sentinel-2 with $10 \mathrm{~m}$ bands, Sentinel- 2 with $10 \mathrm{~m}$ and $20 \mathrm{~m}$ bands, and airborne imagery with $1 \mathrm{~m}$ visible and near-infrared bands. A pixel-based classification approach was used, applying the Random Forests algorithm. The algorithm was trained with 144 plots and 100 decision trees. The results were validated using the hold-out method with 96 independent plots. The most accurate map was obtained using airborne images, the Enhanced Vegetation Index (EVI) and Thiam's Transformed Vegetation Index (TTVI), with an overall accuracy of $88.5 \%$. The map generated from Sentinel- 2 images ( $10 \mathrm{~m}$ bands and the EVI and TTVI spectral indices) had an overall accuracy of $77.1 \%$. Adding $20 \mathrm{~m}$ Sentinel-2 bands and the Normalized Difference Moisture Index (NDMI) did not improve the classification accuracy. According to the most accurate map, 4310 abandoned plots were detected in our study area, representing $32.5 \%$ of its agricultural surface. The proposed methodology proved to be useful for mapping citrus in highly fragmented areas, and it can be adapted to other crops.
\end{abstract}

Keywords: citrus; land abandonment; high-resolution imagery; Sentinel-2; image classification; Random Forests algorithm; machine learning algorithms

\section{Introduction}

Agricultural land abandonment is considered a global issue with relevant environmental and socio-economic consequences [1,2]. The concept of land abandonment (or abandoned land) is complex and not unanimous across all scientific and legal sources. The abandonment of agricultural activity does not always generate a situation of use absence. Sometimes, there is a change in land use 
(for example, urbanization processes or forestry plantations). Thus, it is necessary to differentiate between the broadest concept of abandonment of agricultural activity and the more specific concept of land abandonment, which is reserved for those cases without any land use or economic activity [3-5]. In this study, we use the term land abandonment as the equivalent of agricultural land abandonment or farmland abandonment.

In some European countries, land abandonment is documented to have occurred at other times in history, in the Middle ages, during the nineteenth century due to industrialization, and after World War II [6]. For the 2015-2030 period, it is estimated that around 11\% (more than 20 million hectares) of agricultural land in the European Union (EU) is at risk of abandonment [7]. In the European Mediterranean region, land abandonment is a common issue [8], with variable social, environmental and economic contexts [9]. Mediterranean coastal areas have been one of the most significantly changing areas of Europe due to rapid urbanization, industrialization and tertiarization process [10]. A good example of abandonment due to these processes is the Valencian citrus industry. Spain is the most important citrus producer in the EU and the fifth highest producer in the world [11], and the Valencian Region (East Spain) is its most important producer. Citruses are the main crop in this region, with an area of 165,000 ha, about $60 \%$ of the national area of this crop [12]. It produces more than 3 million Tn of mandarins and oranges annually (50\% and 45\% of the Spain's citrus industry, respectively) [11]. Other important crops in the area are olives (91,843 ha), almonds (91,291 ha) and vineyards (64,407 ha) with minor extension [13]. However, in the areas with freshwater availability and favorable weather conditions, citrus is generally the only crop because it has higher profitability than other crops.

For most of the twentieth century, the economic engine that allowed the accumulation of capital for the industrial development and social modernization of many Valencian areas was orange cultivation [14]. The good situation of international market prices and the absence of competitors brought significant benefits and financial capacity to the extensive social base formed by farmers [15-17], and there was a quick polarization of Valencian agriculture towards citrus. This situation made citrus become the majority crop and the symbol of the Valencian Region. However, in recent years, there has been a massive abandonment of these agricultural holdings due to internal and external causes. There was a significant decrease of 14\% in the citrus-cultivated area from 2008 to 2017 (from 190,000 ha to $165,000 \mathrm{ha}$ ) [12]. The main internal causes are the emergence of more profitable land uses, such as urban use, and the strong competitiveness of foreign producers (outside the EU), so many landowners stop farming their holdings and abandon their plots. In the coming years, an increase in abandoned areas is expected due to the socio-economic changes that are taking place in the EU [18]. Therefore, it is necessary to obtain detailed, descriptive and quantitative information to understand the abandonment consequences in terms of the landscape, the environment and socioeconomics [19]. Land abandonment can generate negative and positive impacts on the environment, depending on the type of crop, the weather, the characteristics of agricultural practices, etc. Among the negative environmental impacts, we can highlight the development of successional vegetation that is highly flammable and increases the risk of forest fires [20]. This vegetation also increases the pressure of weeds, pests and pathogens in nearby agricultural fields [21]. In addition, land abandonment may promote soil erosion [22] and the loss of landscapes of high cultural value and agrobiodiversity [23], and promote soil salinization [24]. On the positive side, agricultural land abandonment can provide environmental services such as carbon sequestration and the mitigation of anthropogenic $\mathrm{CO}_{2}$ emissions due to the vegetation recovery and increase in soil organic matter [25], which also helps in reducing soil erosion [26]. This is especially true in citrus land abandonment and with other crops with flood irrigation and organic matter removal. In these cases, land abandonment can help reduce soil erosion [27].

The effects of land abandonment on the environment and society are complex and need to be studied at different scales. We face current challenges that require the efficient management of agricultural and wilderness areas [28]. This involves food provisioning at efficient scales and maintaining a network of rewild areas that offer trade-offs between food provisioning, ecosystem 
services and biodiversity conservation [29]. In this sense, remote sensing is a powerful tool that allows us to manage these problems (land use and land cover change) from a spatial and temporal point of view at different scales.

Land abandonment and vegetation changes have been studied using remote sensing techniques, but to our knowledge, the abandonment of citrus lands has not been studied. Previous studies have tried to develop methods to estimate citrus production using Landsat images. Although they have found positive correlations between the Landsat results and manual censuses, there are serious discrepancies due to the inability to detect abandoned and unproductive plots using Landsat images [30]. Some previous studies about land abandonment have focused on the use of MODIS (Moderate Resolution Imaging Spectroradiometer) imagery to map land abandonment in large areas, which does not require a high spatial resolution [31-33]. However, most studies have focused on Landsat imagery [34-40]. The spatial resolution of Landsat images also has serious limitations in very heterogeneous areas with high spatial fragmentation. In this sense, Sentinel-2 (with spatial resolutions of $10 \mathrm{~m}$ and $20 \mathrm{~m}$ ) and high-resolution imagery can provide a solution to these limitations. Sentinel-2 use for mapping land abandonment is poorly exploited. Previous studies only differentiate between active crops and highly advanced forest successions [41-43].

In general, previous remote sensing studies about land abandonment have been based on two types of approaches. Firstly, for crops with clearly differentiated phenological states throughout the year, and crops with fallow seasons, the multi-temporal based approach allows the detection of anomalies in phenological dynamics [32,33,36,39,42]. However, this is not characteristic of citrus, which have slow phenological dynamics. Secondly, the mono-temporal approach is based on the detection of succession vegetation that invades abandoned crops [41]. In this study, the mono-temporal approach was chosen, mainly because the characteristics of citrus, but it has other advantages, i.e., it only requires one field campaign for validation, and processing is more efficient because it uses only one image. The success of this strategy depends on the capacity of the sensor and the classification algorithm in capturing differences in characteristics between wild vegetation and active crops.

There are different algorithms for classifying images from remote sensors. These methods range from unsupervised algorithms (i.e., ISODATA or K-means) to parametric supervised algorithms (i.e., maximum likelihood) and machine learning algorithms such as Artificial Neural Networks (ANN), k-Nearest Neighbors (k-NN), Decision Trees (DT), Support Vector Machines (SVM) and Random Forests (RF) [44]. Machine learning algorithms offer the potential for effective and efficient classification, as they are capable of handling high dimensional data and modeling complex nonlinear relationships [45]. Numerous studies have been conducted to find the best classification algorithm for land use and cover studies. However, their conclusions are quite different for different contexts. Despite this, SVM and RF are usually the most accurate algorithms and are insensitive to noise and overtraining [44].

The aim of this work is to compare the performance of Sentinel-2 images and high-resolution airborne images for the mapping of abandoned agricultural plots in a highly heterogenous and fragmented area. We applied a supervised classification based on Random Forest algorithms, and three classification models were compared: Model 1 uses the $10 \mathrm{~m}$ Sentinel-2 bands; Model 2 uses the $10 \mathrm{~m}$ and 20 m Sentinel-2 bands; and Model 3 uses the R, G, B and near infraredbands of airborne images. We mapped the recent land abandonment to differentiate between two types of land cover with very similar spectral responses.

\section{Data and Methods}

\subsection{Study Area}

The study area is Oliva, a coastal city in the Valencian Region (Spain) (Figure 1). In this area, various land uses—such as urban, agricultural and forestry-coexist in a reduced geographic area. The study area is 4,616 ha, and the agricultural land use is approximately $40 \%$. The relief of the area is flat, with an average slope of $2 \%$. There is a gradient from the coast, which is characterized by young 
and little-evolved soils associated with old sandbanks that closed primitive lagoons, to the inland alluvial zone, which is characterized by fluvial materials. Alluvial soils are highly permeable and have higher agronomic capacity [46,47].

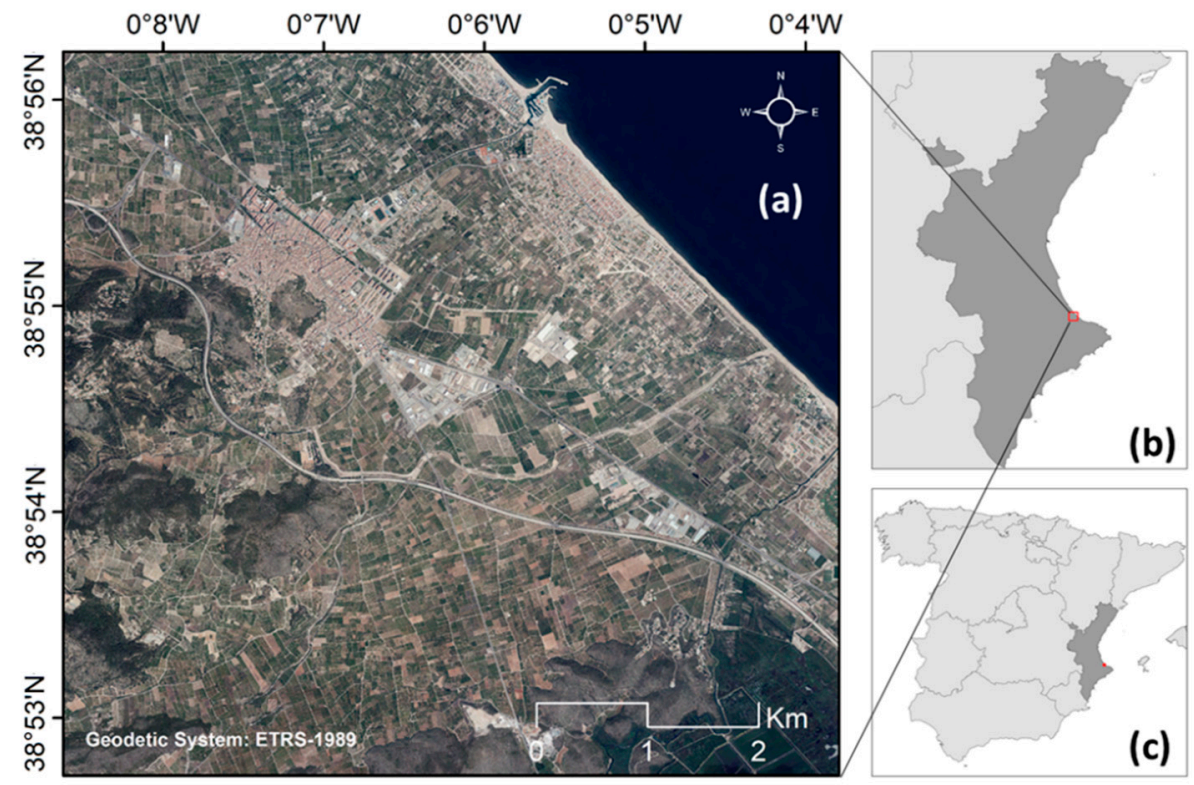

Figure 1. Location of the study area (a) in the Valencian Region (b), Spain (c).

The main crop in this area is citrus, which occupies more than $95 \%$ of the cultivated agricultural area. The average size of the agricultural plots is 0.38 ha \pm 0.27 , and it is representative of many municipalities in the Valencian Region, which had maximum production in the late 1970s and are currently experiencing massive land abandonment.

\subsection{Land Abandonment Process in Citrus}

Three types of plots were classified according to the type of coverage found in the study area (Figure 2): (a) Not in production-these are plots where bare soil occupies most of the surface of the plot. These plots are in replacement periods. In this class, trees may be planted but are generally not yet productive. (b) In production-these are plots with citrus productive cultivation. In this class, the citrus crop occupies most of the surface of the plot. (c) Abandoned-these are abandoned plots dominated by wild vegetation.

In the study area, active crops coexist with several herbaceous species that grow under the tree layer formed by orange trees, although these herbs are usually controlled by farmers. Differences in environmental and soil moisture generate different compositions of vegetation in winter and summer. In winter, species such as Oxalis pes-caprae and Hordeum murinum predominate, while in summer, species like Portulaca oleracea and Setaria verticillata appear.

The ecological succession of an abandoned plot consists of the progressive replacement of the crop by wild vegetation of the area. In the first stage of abandonment, there is a growth of this herbaceous vegetation that extends progressively in the plot. This process occurs from the first to the fourth year after abandonment and is visible by around the third year. The type of the new vegetation and its growth depend on the characteristics of the soil, although species such as Asparagus acutifolius and Imperata cylindrica are common. In the second stage of abandonment, from the fourth or fifth year, the crop loses vigor (there is a decrease in leaf density and greenness) due to the lack of irrigation and the wild vegetation height and cover increase. Finally, the death of the trees can occur, and the wild vegetation occupies the entire plot, even colonizing the trees' remains. This process is completed by the 10th year, approximately. The height of the successive vegetation depends on the type of species 
that appear, although generally, by the 10th year of abandonment, the vegetation measures around $1 \mathrm{~m}$ in height. In this last stage, shrub species appear, such as Rubus ulmifolius and Pistacia lentiscus. Olea europea and Chamaerops humilis may appear occasionally, and exotic species such as Arundo donax may appear in areas with water.

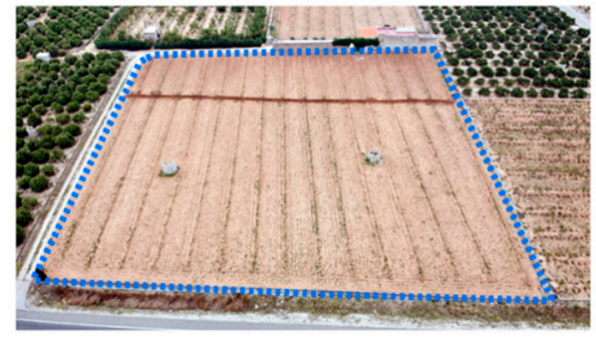

(a)

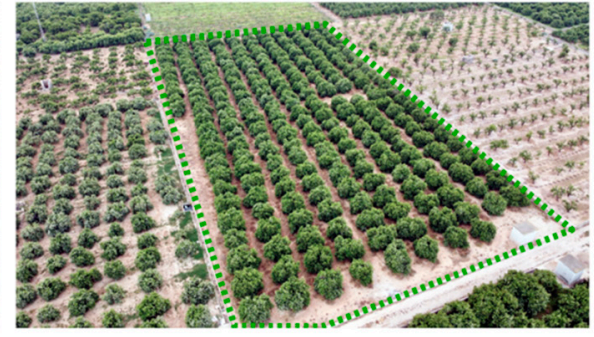

(b)

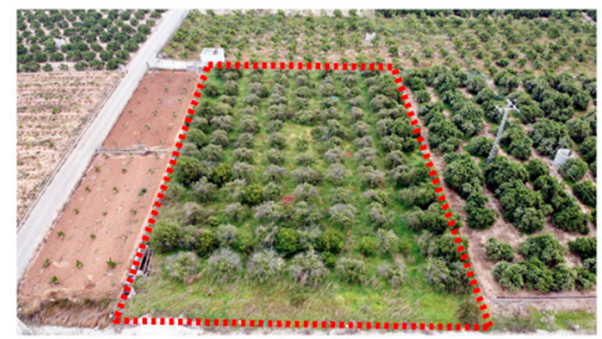

(c)

Figure 2. Types of plots classified according to the type of coverage: (a) not-in-production plot, (b) in-production plot and (c) abandoned plot.

\subsection{Data and Processing}

The image geoprocessing was programmed in an R environment [48] using the raster [49] and rgdal [50] packages.

A Sentinel-2 image acquired on 11 May 2019 with processing level L1C was downloaded from the Copernicus Open Access Hub: https://scihub.copernicus.eu/dhus/\#/home. The Sentinel-2 image was processed as follows (Figure 3). First, it was atmospheric corrected using the Sen2cor algorithm [51]. Then, bands of $20 \mathrm{~m}$ resolution were resampled to $10 \mathrm{~m}$. Finally, four spectral indices were calculated from these images: the Enhanced Vegetation Index (EVI) [52], Thiam's Transformed Vegetation Index (TTVI) [53], and Normalized Difference Moisture Indices, which use Sentinel-2 short-wave infrared or SWIR (Bands 11 and 12 respectively) (NDMI1 and NDMI2) [54]:

$$
\begin{gathered}
\mathrm{EVI}=2.5 * \frac{(\mathrm{NIR}-\mathrm{R})}{(\mathrm{NIR}+6 \mathrm{R}-7,5 \mathrm{~B}+1)} \\
\mathrm{TTVI}=\sqrt{\left|\frac{(\mathrm{NIR}-\mathrm{R})}{(\mathrm{NIR}+\mathrm{R})}\right|+0.5} \\
\mathrm{NDMI}=\frac{(\mathrm{NIR}-\mathrm{SWIR})}{(\mathrm{NIR}+\mathrm{SWIR})}
\end{gathered}
$$

where NIR is the near infrared band, $\mathrm{R}$ is the red band, B is the blue band and SWIR is the short-wave infrared band. The bands of each image are detailed in Table 1. 


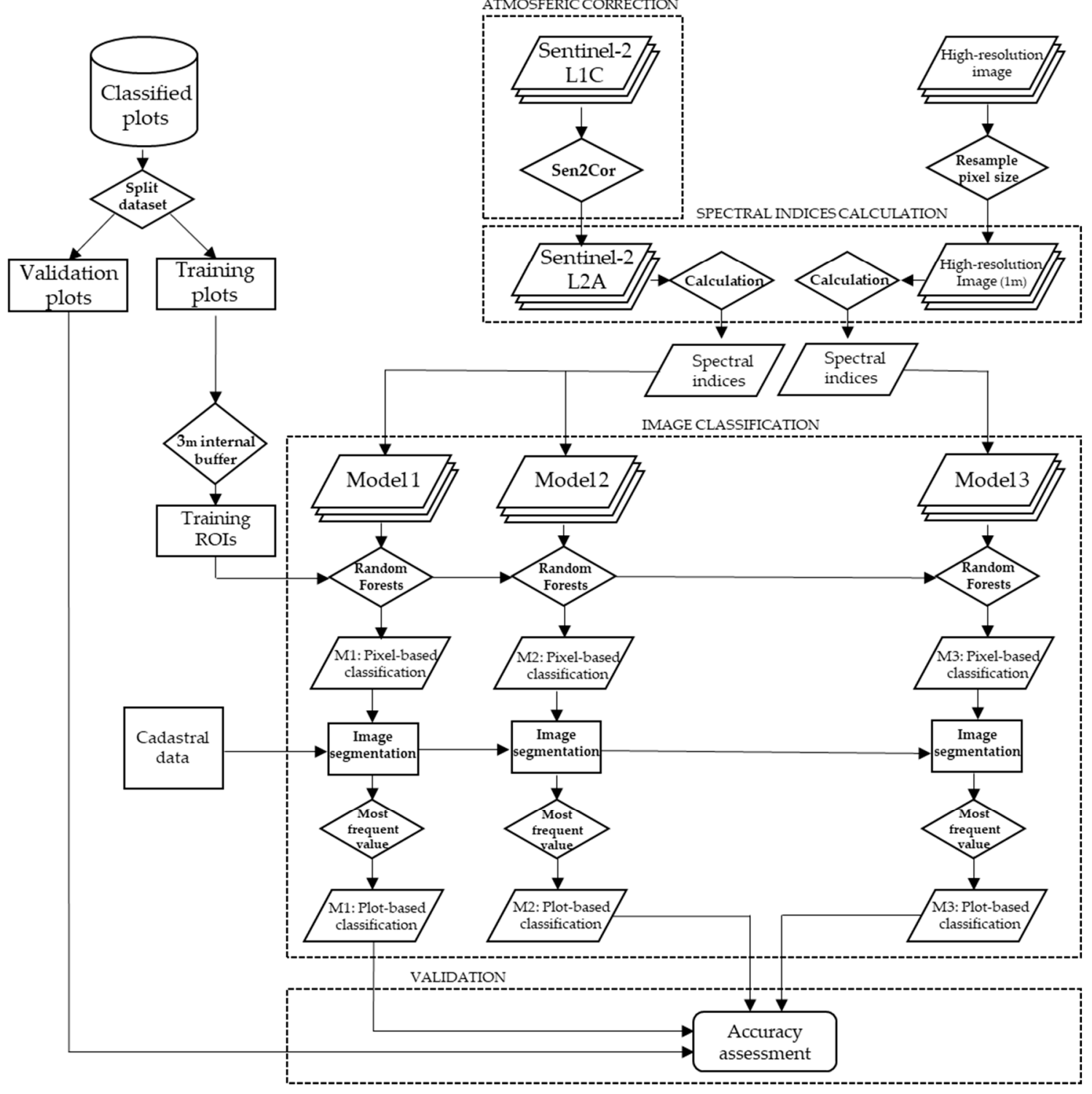

Figure 3. Chart describing the methodology of the experiment.

Table 1. Comparison between the MultiSpectral Instrument bands of Sentinel-2 and Qioptic Vexcel HR Digaron bands of UltraCam Eagle.

\begin{tabular}{|c|c|c|c|c|c|c|}
\hline \multirow[b]{2}{*}{ Chanel } & \multicolumn{3}{|c|}{$\begin{array}{c}\text { Sentinel-2 Imagery } \\
\text { (MultiSpectral Instrument) }\end{array}$} & \multicolumn{3}{|c|}{$\begin{array}{l}\text { High-resolution Airborne Imagery } \\
\text { (UltraCam Eagle) }\end{array}$} \\
\hline & Band & $\begin{array}{c}\text { Central } \\
\text { Wavelength (nm) }\end{array}$ & $\begin{array}{c}\text { Spatial } \\
\text { Resolution (m) }\end{array}$ & Band & $\begin{array}{c}\text { Central } \\
\text { Wavelength }(\mathrm{nm})\end{array}$ & $\begin{array}{c}\text { Spatial } \\
\text { Resolution (m) }\end{array}$ \\
\hline Blue & 2 & 490 & 10 & 3 & 430 & 0.25 \\
\hline Green & 3 & 560 & 10 & 2 & 530 & 0.25 \\
\hline Red & 4 & 665 & 10 & 1 & 620 & 0.25 \\
\hline Red edge 1 & 5 & 705 & 20 & & & \\
\hline Red edge 2 & 6 & 740 & 20 & & & \\
\hline Red edge 3 & 7 & 783 & 20 & & & \\
\hline NIR & 8 & 842 & 10 & 4 & 720 & 0.25 \\
\hline Red edge 4 & $8 \mathrm{~A}$ & 865 & 20 & & & \\
\hline SWIR 1 & 11 & 1610 & 20 & & & \\
\hline SWIR 2 & 12 & 2190 & 20 & & & \\
\hline
\end{tabular}


These three spectral indices were selected to capture differences in characteristics between not-in-production, in-production and abandoned plots. The TTVI is a transformation of the Normalized Difference Vegetation Index (NDVI) that avoids negative values but has no technical differences from the NDVI [55]. This index is sensitive to the vegetation greenness and the biomass amount. However, dense vegetation can saturate this spectral index. The EVI allows the correction of this saturation effect [56]. The NDMI is sensitive to soil and vegetation moisture [54]; it was added to capture the moisture differences that may exist between irrigated plots and abandoned plots (non-irrigated). The possibility of adding other spectral indices such as the Soil-Adjusted Vegetation Index (SAVI) [57] and Green Normalized Difference Vegetation Index (GNDVI) [58] was studied, but this option was rejected due to the high correlation of these indices with the TTVI. Adding these indices could destabilize the classification model. The Spearman's correlations between the indices used were as follows: $\rho_{\text {TTVI-EVI }}: 0.11, \rho_{\text {EVI-NDMI }}: 0.14$ and $\rho_{\text {TTVI-NDMI }}: 0.58$.

High-resolution airborne images were downloaded from the Valencian Spatial Data Infrastructure (IDEV): http://www.idev.gva.es/es. These images were taken on May 14, 2019 with an UltraCam Eagle UC-E-1-50016095-f80 camera from the company Vexcel Imaging GmbH @ with a Qioptic Vexcel HR Digaron sensor. The Valencian Cartographic Institute (ICV) provides an annual image of the entire Valencian Region with a spatial resolution of $0.25 \mathrm{~m}$ and four spectral bands (Table 1). These images were geometrically corrected and radiometrically calibrated by Vexcel Imaging $\mathrm{GmbH}(\mathrm{C}$. According to the company report, the radiometric calibration was based on a series of 50 flat field images for each aperture size and sensor. The flat field was illuminated by eight normal light lamps with known spectral illumination curves. These images were used to calculate the specific sensitivity of each pixel to compensate for local as well as global variations in sensitivity. Sensitivity tables are calculated for each sensor and aperture setting, and applied during the radiometric calibration process for the images. The results of the bundle adjustment showed an RMSE value lower than $4 \mathrm{~cm}$ for the $X, Y$ and $\mathrm{Z}$ coordinates using a set of 22 points according to the calibration report of the company.

Seven images were downloaded and merged to create a single mosaic covering the study area. The mosaic image was resampled to a resolution of $1 \mathrm{~m}$ to reduce the computational requirements and the pixels' spectral variability within each plot. Additionally, two spectral indices were calculated: the EVI [52] (Equation (1)) and TTVI [53] (Equation (2)). The spectral indices calculated from the high-resolution image cannot be compared directly with the indices of the Sentinel-2 images due to the differences in the wavelengths of their spectral bands. The most important difference between both sensors is in the NIR band, which, in fact, is more similar to the Vegetation Red Edge of Sentinel-2 (Table 1).

The ground truth data were collected during a field campaign conducted between 11 and 14 July 2019. A set of 240 plots was selected ( 80 not in production, 80 in production and 80 abandoned). Stratified random sampling with proportional distribution was performed. The original dataset was randomly segmented using 144 training plots and 96 validation plots. The same number of plots for each class was selected for training (48 plots of each class) and validation (32 plots of each class) (Figure 4).

The regions of interest (ROIs) were created by applying an internal buffer of $3 \mathrm{~m}$ on the training plots to avoid the vegetation that occupied the plot boundaries. Each pixel value within these plots was extracted from Sentinel-2 and airborne bands and spectral index to create the set of pixels to train the Random Forests classifiers. Three models were analyzed using the coverage type as the dependent variable. The independent variables of each model were grouped according to the spatial and spectral resolution of the bands of each sensor. Model 1: The pixel values of Bands 2, 3, 4, 8, EVI and TTVI vegetation indices retrieved from the Sentinel-2 images were used as independent variables. These variables have a spatial resolution of $10 \mathrm{~m}$. Model 2: The pixel values of Bands 2, 3, 4, 5, 6, 7, 8, 8A, 11 and 12; the vegetation indices EVI and TTVI; and the moisture indices NDMI1 (Band 11) and NDMI2 (Band 12) were used as independent variables. These variables have a minimum spatial resolution of $20 \mathrm{~m}$. Model 3: The Red, Green, Blue and Near-Infrared bands and the vegetation indices 
EVI and TTVI retrieved from airborne image were used as independent variables. These variables have a spatial resolution of $1 \mathrm{~m}$.
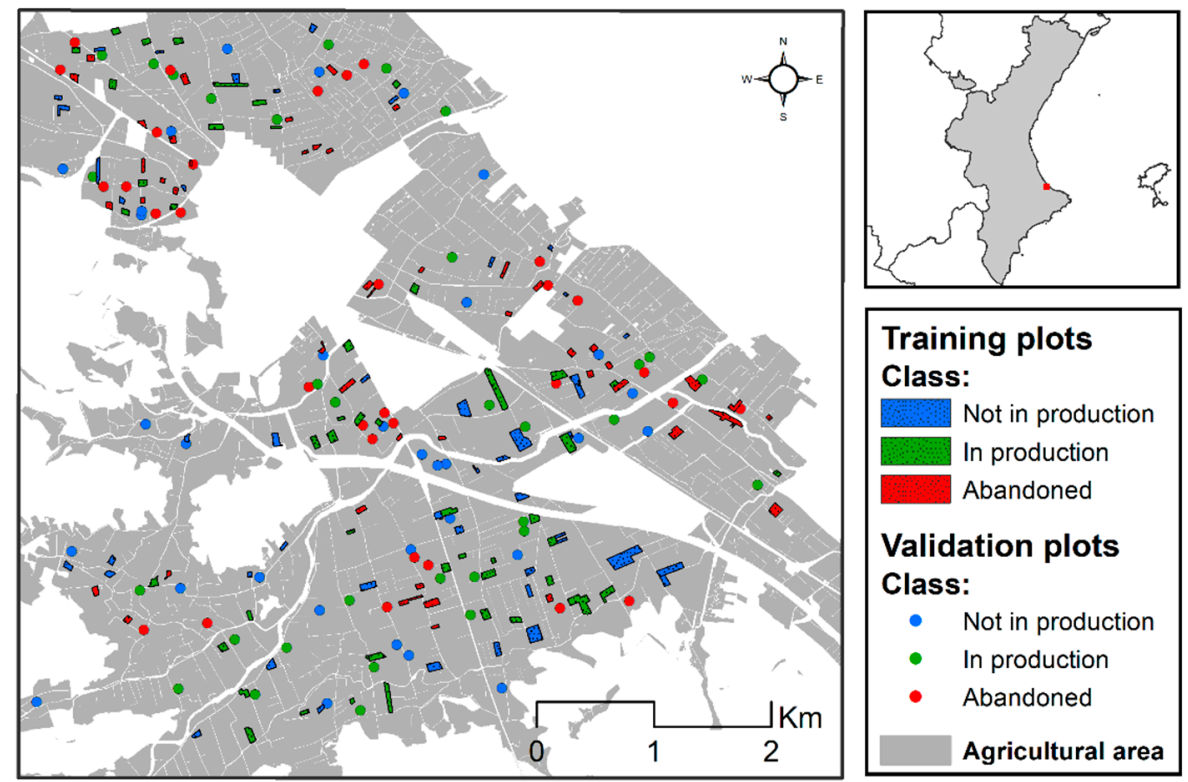

Figure 4. Location of plots surveyed during ground measurements in July 2019. These data were used to create the training dataset and assess classifier performance.

\subsection{Classification Algorithm}

Pixel-based classification was done using Random Forests, which is a non-parametric algorithm commonly used in remote sensing for supervised classifications. This algorithm was proposed by Breiman (1999) [59].

The Random Forests classifier consists of an ensemble of tree classifiers $\left\{h\left(x, \Theta_{k}\right), k=1, \ldots,\right\}$ where the $\left\{\Theta_{k}\right\}$ are independent, identically distributed random vectors and $X$ is an input pattern [60]. In training, the algorithm creates multiple CARTS-like trees [61], each one trained on a bootstrapped sample of the original training data, and searches only across a randomly selected subset of the input variables to determinate a split (for each node) [62]. Bootstrap Aggregation (or Bagging) is the method of selecting a training dataset for each tree by randomly drawing with $\mathrm{N}$ examples, where $\mathrm{N}$ is the size of the original training set [63].

The design of a decision tree required the choice of an attribute selection measure and pruning method. The Random Forests classifier uses the Gini Index as an attribute selection measure, which measures the impurity of an attribute with respect to the classes [64]. For a given training set $\mathrm{T}$, selecting one case (training pixel) at random and saying that it belongs to some class $\mathrm{Ci}$, the Gini Index can be written as:

$$
\sum \sum_{j \neq i}\left(\int(C i, T) /|T|\right)\left(\int(C j, T) /|T|\right)
$$

where $\int(\mathrm{Ci}, \mathrm{T}) / \mathrm{T} \mid$ is the probability that the selected case belongs to class $\mathrm{Ci}$.

The Mean Decrease in Gini (MDG) was used as a measure of the importance of the variables of each model. The Gini importance measures the average gain of purity by splits of a given variable. Therefore, if the variable is useful, it tends to split mixed labeled nodes into pure single class nodes. This means that a variable is important if it is capable of differentiating a class by itself or, in other words generating a single class node. This measure of importance should not be confused with the Mean Decrease Accuracy, which corresponds to the decrease in the average precision of a model when a variable is permuted. 
The number of variables in Bagging and the number of trees grown are user-defined parameters. As the number of trees increases, the generalization error always converges, and overfitting is not a problem because of the Strong Law of Large Numbers. Despite this, the number of trees grown must be limited so as not to excessively increase computing time: $\operatorname{ctv}(\mathrm{MN} \log (\mathrm{N}))$, where $\mathrm{c}$ is a constant, $\mathrm{T}$ is the number of trees in the ensemble, $\mathrm{M}$ is the number of variables and $\mathrm{N}$ is the number of samples in the training dataset [62].

In this work, the Random Forest algorithm was applied using the randomForest function [65] from the caret package [66] in the R environment [48]. Model 1 has six input variables and was trained with pixels covered by 144 training ROIs. Model 2 has 14 input variables and was trained with pixels covered by 144 training ROIs. Model 3 has six input variables and was trained with pixels covered by 144 training ROIs. The classifiers were optimized with 100 decision trees and were trained with the same number of pixels in each category. The generalization errors of the models converged around 100 decision trees (Figure 5). Therefore, a more complex model would require more computing time without improving the classification. The details of each model are shown in Table 2.

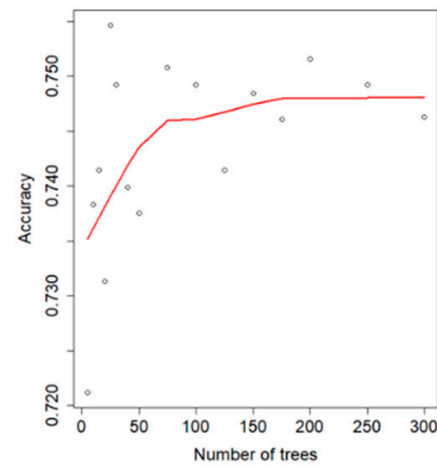

(a)

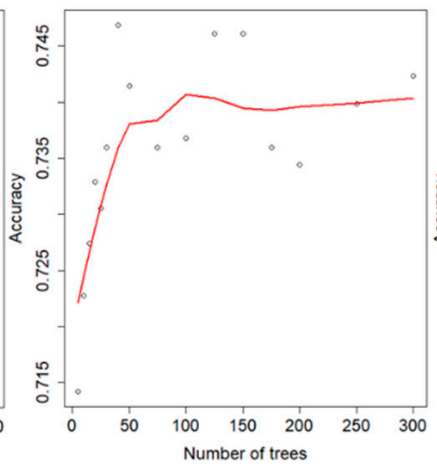

(b)

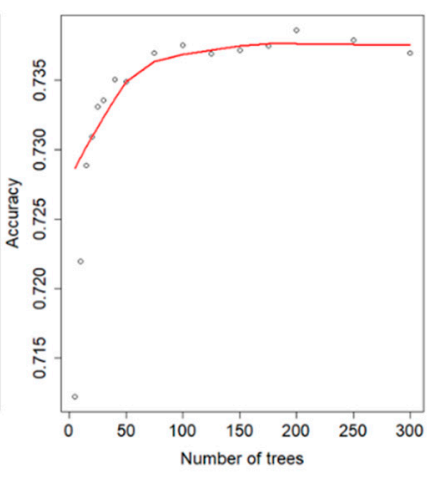

(c)

Figure 5. Convergence of the generalization error of the models. The models were trained with an increasing number of decision trees, and the accuracy of classification was evaluated from the pixel-based classification. The convergence of the three models occurred at around 100 decision trees. Images (a), (b) and (c) show the convergence of Models 1, 2 and 3, respectively.

Table 2. Summary of the parameters used in each model.

\begin{tabular}{|c|c|c|c|c|c|c|}
\hline & Input Variables & $\begin{array}{c}\text { Input } \\
\text { Variables }\end{array}$ & $\begin{array}{l}\text { Training } \\
\text { ROIs (plots) }\end{array}$ & $\begin{array}{l}\text { Samples by } \\
\text { Variable } \\
\text { (pixels) }\end{array}$ & N Trees & $\begin{array}{c}\text { Selected } \\
\text { Variables in Each } \\
\text { Bagging }\end{array}$ \\
\hline Model 1 & $\begin{array}{l}\text { B2, B3, B4, B8, EVI and TTVI } \\
\text { (Sentinel-2) }\end{array}$ & 6 & 144 & 2847 & 100 & 2 \\
\hline Model 2 & $\begin{array}{c}\text { B2, B3, B4, B5, B6, B7, B8, B8A, } \\
\text { B11, B12, EVI, TTVI, NDMI1 } \\
\text { and NDMI2 (Sentinel-2) }\end{array}$ & 14 & 144 & 2847 & 100 & 8 \\
\hline Model 3 & $\begin{array}{c}\text { B1, B2, B3, B4, EVI and TTVI } \\
\text { (High-resolution image) }\end{array}$ & 6 & 144 & 283,329 & 100 & 2 \\
\hline
\end{tabular}

The image classified by pixels was masked to remove other land uses. The cadastral data were used to frame urban areas. Later, the rustic areas where agricultural use is not allowed were masked through the cartography of the Forest Territorial Action Plan of the Valencian Region (PATFOR). The resulting image was segmented using a cadastral layer that defines agricultural plots. Finally, each plot was classified as an object following the most frequent pixel value criteria inside the plot.

\subsection{Accuracy Assessment and Validation}

A key issue in the classification of remote sensing images is the evaluation of the results' precision [63]. Originating from traditional validation methods for pixel-based classifications, many object-based image 
analysis (OBIA) results have been assessed by point-based sampling, although object-based strategies are highly recommended [67-69]. A polygon that represents a meaningful and homogenous patch of land is more suitable for accuracy assessments of maps that are produced with OBIA [67,70,71]. In this case, the agricultural plots are clearly defined units that present a homogeneous and independent behavior of the neighboring plots. For this reason, an evaluation approach based on plots was used.

For the accuracy assessment, 96 plots were randomly selected. The same number of plots of each class were selected to calculate the overall accuracy, user accuracy and producer accuracy. Finally, the area of the misclassified and correctly classified plots was computed, and basic statistics were calculated to determine possible relationships between the classification precision and the size of the plots.

\section{Results}

According to the classification of agricultural plots in the cadastral database, the agricultural area was segmented into 11,305 plots that occupy around 1900 Ha. Table 3 compares the area and the number of parcels classified as not in production, in production and abandoned by each model. The surface classified by each model was similar, but Model 3 classified more abandoned plots and plots not in production than Models 1 and 2. The spatial distribution of abandoned plots was similar in the three models, which indicates that there are more abandoned parcels in the coastal zone (Figure 6).

Table 3. Classification results of each model used.

\begin{tabular}{ccccccc}
\hline & $\begin{array}{c}\text { Not-in-Production } \\
\text { Plots }\end{array}$ & $\begin{array}{c}\text { Not-in-Production } \\
\text { Surface (\%) }\end{array}$ & $\begin{array}{c}\text { In-Production } \\
\text { Plots }\end{array}$ & $\begin{array}{c}\text { In-Production } \\
\text { Surface (\%) }\end{array}$ & $\begin{array}{c}\text { Abandoned } \\
\text { Plots }\end{array}$ & $\begin{array}{c}\text { Abandoned } \\
\text { Surface (\%) }\end{array}$ \\
\hline Model 1 & 2080 & 14.3 & 5069 & 51.0 & 4156 & 34.6 \\
Model 2 & 2308 & 16.0 & 4959 & 51.9 & 4038 & 32.1 \\
Model 3 & 2415 & 15.4 & 4587 & 52.2 & 4303 & 32.2 \\
\hline
\end{tabular}
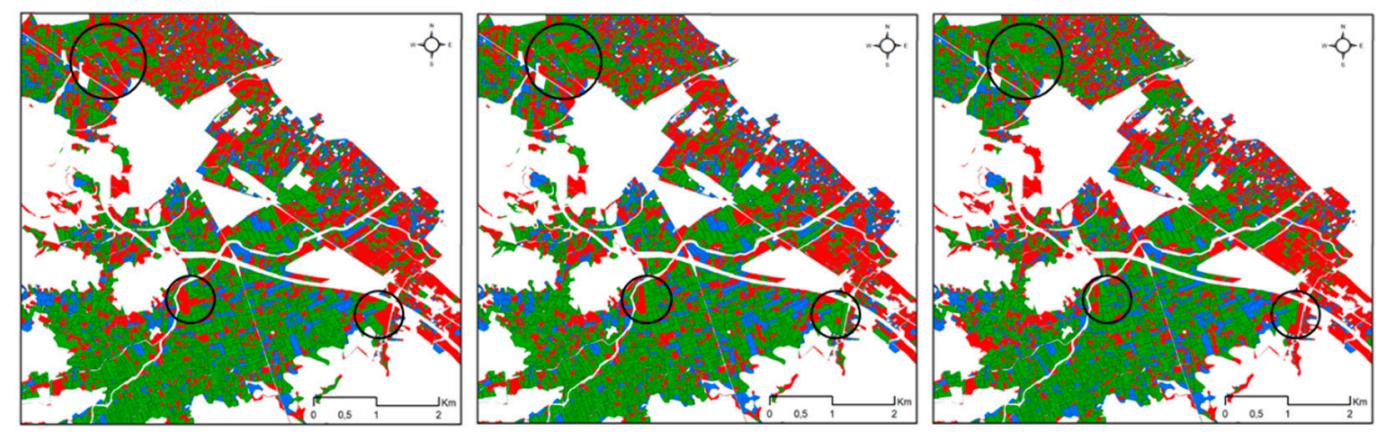

NOT IN PRODUCTION $\square$ IN PRODUCTION $\square$ ABANDONED

(a)

(b) (c)

Figure 6. Land abandonment map generated by each model. Model 1 (a), Model 2 (b) and Model 3 (c). The circles show areas where the models predicted differently.

Table 4 shows the overall accuracy for each model. The most accurate map was obtained with Model 3 (Figure 7), which uses high-resolution airborne images. This model improved, by more than $10 \%$, the accuracy of Models 1 and 2, which use Sentinel-2 images. Adding the Sentinel-2 $20 \mathrm{~m}$ bands did not improve the classification accuracy.

The not-in-production class was easily detectable by all the models, with producer accuracies close to $100 \%$. The distinguishing between in-production and abandoned classes was more inaccurate due to a similar spectral response. All the models obtained a classification accuracy for the abandoned class of 78\%; however, Model 3 improved the classification accuracy for the in-production class compared to the other models. Model 3 obtained the best results for the differentiation of these two classes, 
with a producer's accuracy of $87.5 \%$ for the in-production class and $78.1 \%$ for the abandoned class. The confusion matrices for each model are shown in Table 5.

Table 4. Summary of accuracies obtained with each model.

\begin{tabular}{lc}
\hline & $\begin{array}{c}\text { Overall Accuracy } \\
\text { (c.i. 95\%) }\end{array}$ \\
\hline Model 1 & $77.1 \%$ \\
Model 2 & $76.0 \%$ \\
Model 3 & $88.5 \%$ \\
\hline
\end{tabular}
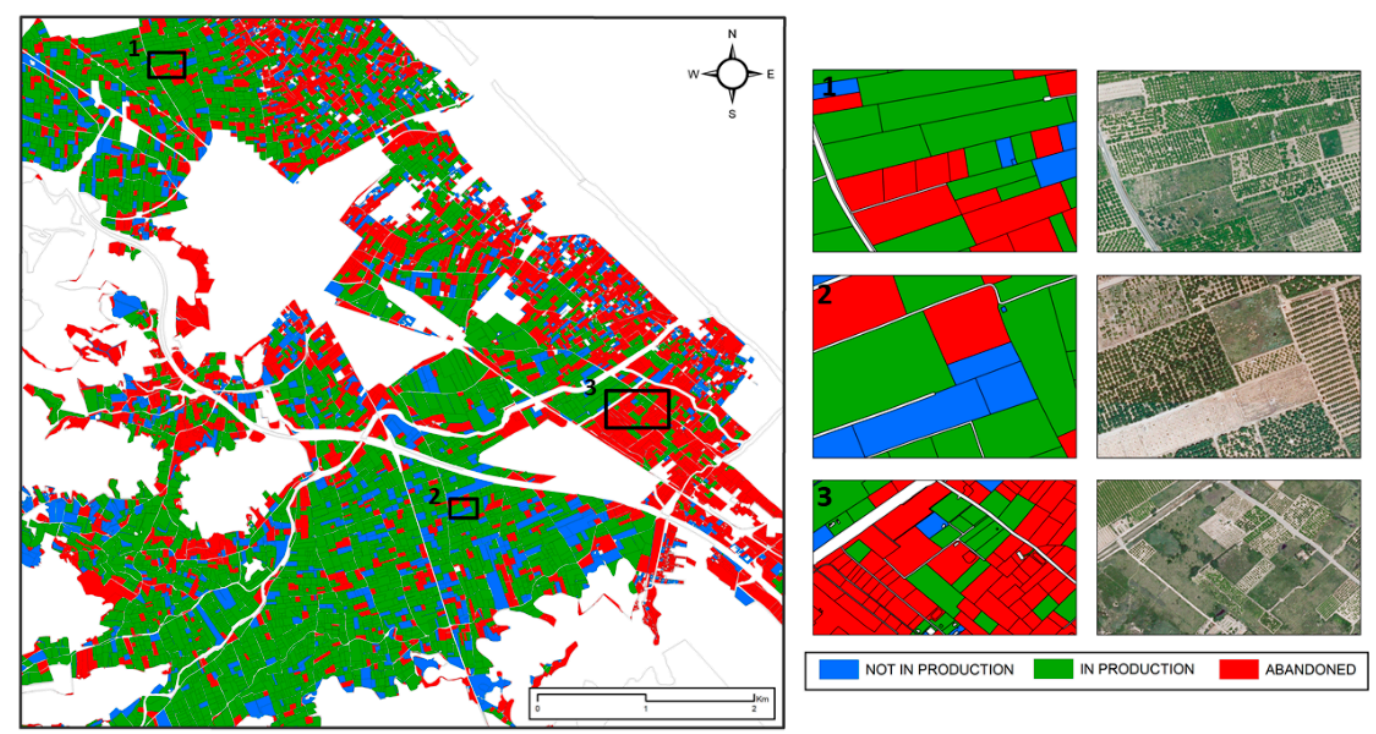

Figure 7. Model 3 map.

The analysis of the validation plot area shows that the Sentinel-2 images tend to fail with small plots (Figure 8). The average size of the 22 plots misclassified by Model 1 was $3416 \mathrm{~m}^{2} \pm 2392$, while the 74 correctly classified plots have an average area of $3986 \mathrm{~m}^{2} \pm 2845$. This difference was larger for Model 2, which uses lower resolution bands $(20 \mathrm{~m})$. The average size of the 23 plots misclassified by this model was $2798 \mathrm{~m}^{2} \pm 1838$, while the average size of the 73 plots correctly classified was $4162 \mathrm{~m}^{2} \pm 2895$. By contrast, the accuracy of Model 3 is not affected by the size of the plots. The average area of the 11 plots misclassified by Model 3 was $3956 \mathrm{~m}^{2} \pm 3035$, while the average area of the 85 plots classified correctly was $3834 \mathrm{~m}^{2} \pm 2717$.

According to the Gini results (Figure 9), the TTVI was the most important variable in general. This means that the TTVI was able to separate categories by itself. TTVI was the most important variable in Models 1 and 2 using Sentinel-2 bands. In Model 3, the TTVI was the second most important variable. This last result may be related to the wavelength offset of the NIR band of the high-resolution image towards the red edge. The red band was also very important in Models 1 and 3. In Model 2, the NDMI1 was the second most important variable for pixel classification. However, adding these variables did not improve the classification accuracy of the plots. According to our interpretation, this means that the NDMI1 may differentiate between abandoned and in-production plots, but the pixel size is not enough in our study area. Model 2 did not improve compared to Model 1 because most of the plots correctly classified by the NDMI1 could also be correctly classified by the TTVI. 
Table 5. Model confusion matrix.

\begin{tabular}{|c|c|c|c|c|c|}
\hline \multicolumn{6}{|c|}{ Model 1} \\
\hline \multirow{2}{*}{ Classified data } & \multicolumn{3}{|c|}{ Reference Data } & \multirow[b]{2}{*}{ Total Map } & \multirow[b]{2}{*}{$\begin{array}{c}\text { User's } \\
\text { Accuracy }\end{array}$} \\
\hline & $\begin{array}{c}\text { Not in } \\
\text { Production }\end{array}$ & Inproduction & Abandoned & & \\
\hline Not in production & 31 & 4 & 2 & 37 & $83.8 \%$ \\
\hline In production & 0 & 18 & 5 & 23 & $78.3 \%$ \\
\hline Abandoned & 1 & 10 & 25 & 36 & $69.4 \%$ \\
\hline Total field & 32 & 32 & 32 & & \\
\hline Producer's accuracy & $96.9 \%$ & $56.3 \%$ & $78.1 \%$ & & \\
\hline \multicolumn{6}{|c|}{ Model 2} \\
\hline \multirow{2}{*}{ Classified Data } & \multicolumn{3}{|c|}{ Reference Data } & & \\
\hline & $\begin{array}{c}\text { Not in } \\
\text { Production }\end{array}$ & In Production & Abandoned & Total Map & $\begin{array}{l}\text { User's } \\
\text { Accuracy }\end{array}$ \\
\hline Not in production & 31 & 3 & 0 & 34 & $91.2 \%$ \\
\hline In production & 0 & 17 & 7 & 24 & $70.8 \%$ \\
\hline Abandoned & 1 & 12 & 25 & 38 & $65.8 \%$ \\
\hline Total field & 32 & 32 & 32 & & \\
\hline Producer's accuracy & $96.9 \%$ & $53.1 \%$ & $78.1 \%$ & & \\
\hline \multicolumn{6}{|c|}{ Model 3} \\
\hline \multirow{2}{*}{ Classified Data } & \multicolumn{3}{|c|}{ Reference Data } & & \\
\hline & $\begin{array}{c}\text { Not in } \\
\text { Production }\end{array}$ & In Production & Abandoned & Total Map & $\begin{array}{c}\text { User's } \\
\text { Accuracy }\end{array}$ \\
\hline Not in production & 32 & 2 & 0 & 34 & $94.1 \%$ \\
\hline In production & 0 & 28 & 7 & 35 & $80.0 \%$ \\
\hline Abandoned & 0 & 2 & 25 & 27 & $92.6 \%$ \\
\hline Total field & 32 & 32 & 32 & & \\
\hline Producer's accuracy & $100 \%$ & $87.5 \%$ & $78.1 \%$ & & \\
\hline
\end{tabular}

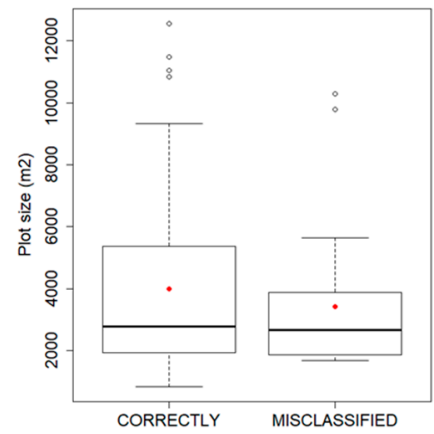

(a)

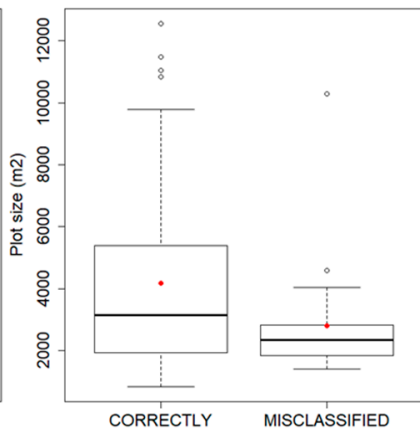

(b)

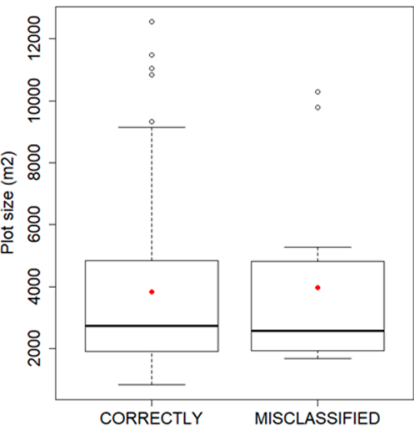

(c)

Figure 8. Boxplots of the plots correctly classified and misclassified by Model 1 (a), Model 2 (b) and Model 3 (c). 


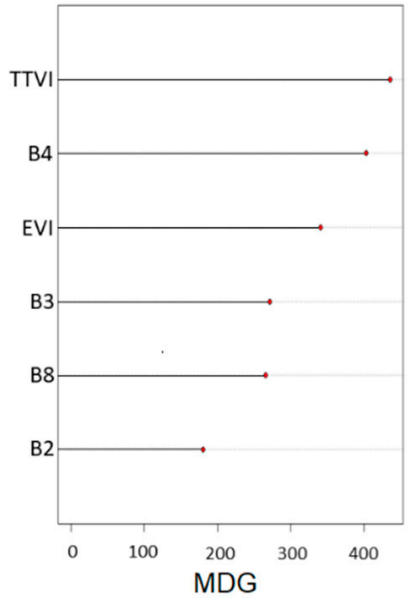

(a)

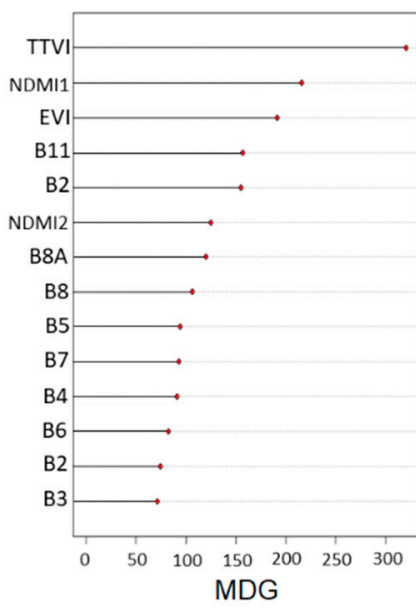

(b)

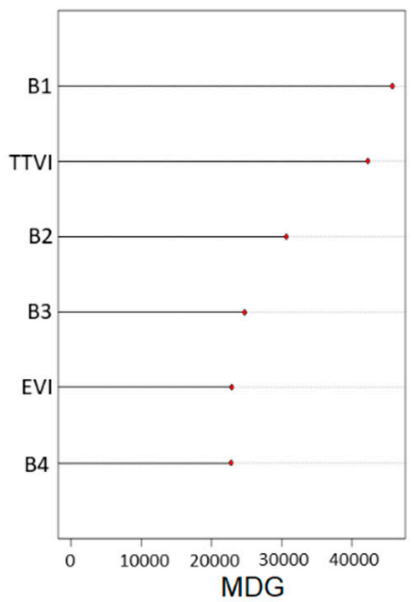

(c)

Figure 9. Importance of the variables according to Mean Decrease in Gini. Importance of Model 1 variables (a), Model 2 (b) and Model 3 (c).

\section{Discussion}

Our results showed that high-resolution airborne images with four spectral bands generate more accurate results than Sentinel-2 images for mapping abandoned citrus plots. High-resolution images were the best alternative for the study of abandonment at the cadastral plot level. However, processing these images is more costly from a computational point of view than processing Sentinel-2 images. Adding $20 \mathrm{~m}$ Sentinel-2 bands did not improve the accuracy of the classification, despite havingmore spectral information. The NDMI calculated from the $20 \mathrm{~m}$ bands of Sentinel- 2 was not able to improve the classification accuracy. This is because the spatial resolution of these bands is not sufficient for the small plots in our study area. This fact does not exclude the use of the NDMI to detect abandonment in other less-fragmented areas, since it was an important variable according to the Gini Index. Although the map accuracy at the plot level was higher for high-resolution images, the abandoned areas obtained with both sources of information were similar. Our results show that Sentinel-2 images tend to fail with small plots. These results show that the resolution of Sentinel-2 images has limitations for the detection of abandonment in highly fragmented areas. However, the ability of Sentinel-2 images to correctly classify large plots may mask better apparent performance. This behavior can explain the similar surface area obtained using both sources of information. Despite these limitations, Sentinel-2 probably offers better results than Landsat in fragmented areas due to its higher spatial resolution, but this should be studied.

The spatial distribution of the abandoned plots is in accordance with our previous experience [72]. There is a high concentration of abandoned plots in the coastal zone due to the lower agronomic capacity of the soils and the prospects for urban growth. In the coastal area, many owners keep their plots without agricultural interest, and they expect future urban processes. There is also a high concentration of abandoned plots adjacent to urban areas where future urban expansion is expected. The active and replacement (in production and not in production) plots are located in the inland area, where the soils are more productive and the crops are less exposed to the cold winds from the east. In this area, the citrus is harvested sooner and acquires greater market value.

The proposed methodology was adequate for studying the abandonment of citrus at the cadastral plot level. Our results recommend the use of high-resolution images for studies that require high precision at the plot level. However, performing the detection of changes based on multiple dates with different sensors requires the radiometric normalization of the images. Some radiometric standardization techniques have already been developed for the detection of citrus changes [73]. This is one of the main drawbacks of using high-resolution airborne images compared to Sentinel-2. 
The availability of high-resolution images with four spectral bands for the entire Valencian territory since 2017 allows a retrospective investigation of the issue. Mapping the citrus land abandonment in the Valencian Region during recent years could help to better understanding of this problem, the detection of hot spots and the spatial location of actions to improve the landscape. The use of these images could help to automate the process of estimating annual citrus production in the Valencian Region. This would allow us to predict the economic impact of citrus based on the analysis of airborne spectral data to determine final crop harvests. Our study provides an overview of the capabilities of airborne images for authorities who wish to implement a monitoring system based on airborne images. This methodology could be applied in other areas of the planet with small plots of citrus or other types of crops when land abandonment is associated with the growth of wild vegetation. In other areas and for other types of crops, the success of the classification will depend on the ability of the sensor to discriminate between wild vegetation and crops. It would be interesting to test this methodology for other types of crops, since these may result in different classification accuracy. Other types of airborne or satellite images could also be processed following this methodology. This would reduce the error in the estimation of citrus production reported by other authors in other areas such as Florida (USA) using images of moderate resolution [30].

Although the use of high-resolution images is appropriate, we do not exclude the use of Sentinel-2 images for studies looking at general land-abandonment trends, and the plot level is not as important. The use of Sentinel-2 images is the best alternative when other types of images that are more expensive and computationally demanding are not available. Sentinel-2 can be useful for detecting land abandonment in areas where, probably, the Landsat resolution is not high enough. Furthermore, these images could improve the accuracy of the maps created with Landsat in previous studies [38]. High-resolution imagery currently has little applicability for large-area studies due to these images not being open access and the high computational requirements. However, Sentinel-2 images are free and have global spatial coverage and a temporal resolution of 5 days. In addition, new cloud-based processing technologies allow these images to be used on a large areas efficiently. More research is needed to test Sentinel-2 images using methodologies for mapping abandoned land proposed by other authors $[33,36,40]$.

Future studies could exploit other approaches using these images. High-resolution images allow other approaches such as object-based classification by adding spatial and textural variables to classification models. This approach could increase object-level classification accuracy, differentiate more specific subcategories, or even provide information about crop age. On the other hand, the 5-day temporal resolution of the Sentinel-2 images allows a multi-temporal approach to mapping land abandonment. It would be interesting to evaluate the performance of Sentinel- 2 images with these methodologies that have already been tested with other types of lower resolution images [31,32,36]. Although, a priori, this strategy is not the most appropriate for mapping the abandonment of citrus lands, this approach should be studied. A multi-time approach can also be useful for discriminating other types of crops, in mixed areas.

Remote sensing technology can be used to obtain spatial and temporal information about different ecosystem services and trade-offs. In this study, we have been able to map land abandonment in a highly fragmented crop, and in a studyarea with different types of soils at specific times. These results can be applied for monitoring agricultural ecosystems, providing useful information for their management. Future investigation with a multi-temporal approach will allow the study of the impact of land use change on soil properties. The abandonment of such an intensive activity as citrus farming can produce a recovery in soil properties. In this detrital plain, soils have very important environmental value and should also be considered in management plans [74].

\section{Conclusions}

Citrus land abandonment was studied in a highly fragmented area using a mono-temporal approach and pixel-based classification with the Random Forests algorithm. The methodology used allowed 
the successful mapping of the abandonment of citrus lands using the Sentinel-2 and high-resolution airborne images. The plot-based map accuracy assessment confirmed the reliability of our approach. High-resolution airborne images showed better accuracies at the plot level (overall accuracy, 88.5\%). However, at the surface level, both sources of information produced similar results. This is because Sentinel-2 images misclassify many small parcels but are able to correctly classify large parcels. Our results show that Sentinel-2 images tend to fail with small plots. The use of $20 \mathrm{~m}$ Sentinel-2 bands did not improve the classification accuracy. Furthermore, adding $20 \mathrm{~m}$ bands generated the misclassification of more small plots. Our results suggest the use of high-resolution images for studies that require a level of detail of the cadastral plot. Meanwhile, Sentinel-2 images can be used for studies that do not need as much detail. Ultimately, our methodology for mapping land abandonment can lead to a deeper understanding of land use and land cover change and allows its application with other images, in other areas and for other types of crops.

Author Contributions: Conceptualization, S.M.-M., J.E. and M.-T.S.-F.; formal analysis, S.M.-M.; investigation, S.M.-M., J.E., M.-T.S.-F.; methodology, S.M.-M., J.E. and M.-T.S.-F.; resources, S.M.-M.; software, S.M.-M.; writing - original draft, S.M.-M.; writing — review and editing, J.E. and M.-T.S.-F. All authors have read and agreed to the published version of the manuscript.

Funding: This research received no external funding.

Conflicts of Interest: The authors declare no conflict of interest.

\section{References}

1. MacDonald, D.; Crabtree, J.R.; Wiesinger, T.; Dax, T.; Stamou, N.; Fleury, P.; Lazpita, J.G.; Gibon, A. Agricultural abandonment in mountain areas or Europe: Environmental consequences and policy response. J. Environ. Manag. 2000, 59, 47-69. [CrossRef]

2. Kosmas, C.; Kairis, O.; Karavitis, C.; Acikalin, S.; Alcalá, M.; Alfama, P.; Atlhopheng, J.; Barrera, J.; Belgacem, A.; Solé-Benet, A.; et al. An exploratory analysis of land abandonment drivers in areas prone to desertification. CATENA 2015, 128, 252-261. [CrossRef]

3. Corbelle-Rico, E.; Crecente-Maseda, R. Estudio da evolución da superficie agrícola na comarca da Terra Chá a partir de fotografía aérea histórica e mapas de usos, 1956-2004. Recur. Rurais 2018, 4, 57-65.

4. Baudry, J. Ecological consequences of grazing extensification and land abandonment: Role of interactions between environment, society and techniques. In Land Abandonment and Its Role in Conservation, 1st ed.; Baudry, J., Bunce, R.G.H., Eds.; Options Méditerranéennes: Série A; Séminaires Méditerranéens: Zaragoza, Spain, 1991; Volume 15, pp. 13-19.

5. Pinto-Correia, T. Land abandonment: Changes in the land use patterns around the Mediterranean basin. Etat de l'Agriculture en Méditerranée. Les sols dans la région méditerranéenne: Utilisation, gestion et perspectives d'évolution. Options Méditerranéennes Série A Séminaires Méditerranéens 1991, 1, 13-19.

6. Gellrich, M.; Baur, P.; Koch, N.; Zimmermann, E. Agricultural land abandonment and natural forest re-growth in the Swiss mountains: A spatially explicit economic analysis. Agric. Ecosyst. Environ. 2007, 118, 93-108. [CrossRef]

7. Perpiña-Castillo, C.; Kavalov, B.; Diogo, V. Agricultural Land Abandonment in the EU within 2015-2030; (Technical Report JRC113718); European Commission: Brussels, Belgium, 2018.

8. Rey-Benayas, J. Abandonment of agricultural land: An overview of drivers and consequences. CAB Rev. Perspect. Agric. Vet. Sci. Nutr. Nat. Resour. 2007, 2, 57. [CrossRef]

9. Romero-Díaz, A.; Martínez-Hernández, C. Usos del suelo y abandono de tierras de cultivo en el altiplano Jumilla-Yecla (Región de Murcia). In Geoecología, Cambio Ambiental y Paisaje: Homenaje al Profesor José María García-Ruiz; Instituto Pirenaico de Ecología: Zaragoza, Spain, 2014; pp. 461-470.

10. Árgyelán, T. Abandonment phenomenon in Europe. Acta Univ. Sapientiae Agric. Environ. 2015, 7, 89-97. [CrossRef]

11. Instituto Valenciano de Investigaciones Agrarias (IVIA). Citricultura Valenciana: Gestión Integrada de Plagas y Enfermedades en Cítricos. Available online: http://gipcitricos.ivia.es/citricultura-valenciana (accessed on 11 May 2020). 
12. Ministerio de Agricultura y Pesca, Alimentación y Medio Ambiente. ESYRCE: Encuesta Sobre Superficies y Rendimientos; (N.I.P.O.: 013-17-120-0.); Ministerio de Agricultura y Pesca, Alimentación y Medio Ambiente: Madrid, Spain, 2017.

13. Conselleria de Agricultura, Desarrollo Rural, Emergencia Climática y Transición Ecológica. In Informe del Sector Agrario Valenciano 2019; Generalitat Valenciana: Valencia, Spain, 2020.

14. Noguera, J. Viabilidad y competitividad del sistema citrícola valenciano. Boletín Asoc. Geógrafos Españoles 2010, 52, 81-99.

15. Tomás-Carpi, J.A. La economía valenciana: Modelos de interpretación. In Contribución Invisible de las Mujeres en la Economía: El Caso Específico del Mundo Rural, 1st ed.; Vera, A., Ed.; Instituto De La Mujer: Madrid, Spain, 1977.

16. Piqueras, J. El Espacio Valenciano. Una Síntesis Geográfica, 1st ed.; Gules: Valencia, Spain, 1999.

17. Salom, J.; Albertos, J.M. El modelo de desarrollo de la Comunidad Valenciana. In La Comunidad Valenciana en la Europa de las Regiones, 1st ed.; Romero, J.S.J., Vera, F., Eds.; Ariel Geografía: Valencia, Spain, 2001.

18. Rounsevell, M.D.A.; Reginster, I.; Araújo, M.B.; Carter, T.R.; Dendoncker, N.; Ewert, F.; House, J.I.; Kankaanpää, S.; Leemans, R.; Metzger, M.J.; et al. A coherent set of future land use change scenarios for Europe. Agric. Ecosyst. Environ. 2006, 114, 57-68. [CrossRef]

19. Verbug, P.H.; Schulp, C.J.E.; Witte, N.; Veldkamp, A. Downscaling of land use change scenarios to assess the dynamics of European landscapes. Agric. Ecosyst. Environ. 2006, 114, 39-56. [CrossRef]

20. Dubinin, M.; Potapov, P.; Lushchekina, A.; Radeloff, V.C. Reconstructing long time series of burned areas in arid grasslands of southern Russia by satellite remote sensing. Remote Sens. Environ. 2010, 114, 1638-1648. [CrossRef]

21. Smelansky, I.E. Biodiversity of Agricultural Lands in Russia: Current State and Trends. In UICN-The World Conservation Union; Ladonina, N.N., Gorelova, Y.V., Chernyakhovsky, D.A., Eds.; IUCN Representative Office for Russia and CIS: Moscow, Russia, 2003; p. 52.

22. Ruiz-Flano, P.; Garcia-Ruiz, J.M.; Ortigosa, L. Geomorphological evolution of abandoned fields. A case study in the Central Pyrenees. CATENA 1992, 19, 301-308. [CrossRef]

23. Fischer, J.; Hartel, T.; Kuemmerle, T. Conservation policy in traditional farming landscapes. Conserv. Lett. 2012, 5, 167-175. [CrossRef]

24. Penov, I. The use of irrigation water in Bulgaria's Plovdiv Region during transition. Environ. Manag. 2004, 34, 304-313. [CrossRef]

25. Novara, A.; Gristina, L.; Sala, G.; Galati, A.; Crescimanno, M.; Cerdà, A.; Badalamenti, E.; La Mantia, T. Agricultural land abandonment in Mediterranean environment provides ecosystem services via soil carbon sequestration. Sci. Total Environ. 2017, 576, 420-429. [CrossRef] [PubMed]

26. Cerdà, A.; Ackermann, O.; Terol, E.; Rodrigo-Comino, J. Impact of Farmland Abandonment on Water Resources and Soil Conservation in Citrus Plantations in Eastern Spain. Water 2019, 11, 824. [CrossRef]

27. Cerdà, A.; Brevik, C.E. The impact of abandonment of traditional flood irrigated citrus orchards on soil infiltration and organic matter. In Geoecología, Cambio Ambiental y Paisaje: Homenaje al profesor José María García-Ruiz; Instituto Pirenaico de Ecología: Zaragoza, Spain, 2014; pp. 267-276.

28. Rey-Benayas, J.M.; Bullock, J.M. Restoration of Biodiversity and Ecosystem Services on Agricultural Land. Ecosystems 2012, 15, 883-899. [CrossRef]

29. Navarro, L.M.; Pereira, H.M. Rewilding Abandoned Landscapes in Europe. In Rewilding European Landscapes, 21st ed.; Pereira, H.M., Navarro, L.M., Eds.; Springer: Berlin/Heidelberg, Germany, 2016; Volume 26, pp. 3-25.

30. Shrivastava, R.J.; Gebelein, J.L. Land cover classification and economic assessment of citrus groves using remote sensing. ISPRS J. Photogramm. Remote Sens. 2007, 61, 341-353. [CrossRef]

31. Löw, F.; Prishchepov, F.; Waldner, F.; Dubovyk, O.; Akramkhanov, A.; Biradar, C.; Lamers, J. Mapping Cropland Abandonment in the Aral Sea Basin with MODIS Time Series. Remote Sens. 2018, 10, 159. [CrossRef]

32. Alcántara, C.; Kuemmerle, T.; Prishchepov, A.V.; Radeloff, V.C. Mapping abandoned agriculture with multi-temporal MODIS satellite data. Remote Sens. Environ. 2012, 124, 334-347. [CrossRef]

33. Estel, S.; Kuemmerle, T.; Alcántara, C.; Levers, C.; Prishchepov, A.V.; Hostert, P. Mapping farmland abandonment and recultivation across Europe using MODIS NDVI time series. Remote Sens. Environ. 2015, 163, 312-325. [CrossRef] 
34. Dara, A.; Baumann, M.; Kuemmerle, T.; Pflugmacher, D.; Rabe, A.; Griffiths, P.; Hölzel, N.; Kamp, J.; Freitag, M.; Hostert, P. Mapping the timing of cropland abandonment and recultivation in northern Kazakhstan using annual Landsat time series. Remote Sens. Environ. 2018, 213, 49-60. [CrossRef]

35. Müller, D.; Leitão, P.J.; Sikor, T. Comparing the determinants of cropland abandonment in Albania and Romania using boosted regression trees. Agric. Syst. 2013, 117, 66-77. [CrossRef]

36. Yin, H.; Prishchepov, A.V.; Kuemmerle, T.; Bleyhl, B.; Buchner, J.; Radeloff, V.C. Mapping agricultural land abandonment from spatial and temporal segmentation of Landsat time series. Remote Sens. Environ. 2018, 210, 12-24. [CrossRef]

37. Kuemmerle, T.; Hostert, P.; Radeloff, V.C.; Linden, S.; Perzanowski, K.; Kruhlov, I. Cross-border Comparison of Post-socialist Farmland Abandonment in the Carpathians. Ecosystems 2008, 11, 614-628. [CrossRef]

38. Grădinaru, S.R.; Kienast, F.; Psomas, A. Using multi-seasonal Landsat imagery for rapid identification of abandoned land in areas affected by urban sprawl. Ecol. Indic. 2019, 96, 79-86. [CrossRef]

39. Prishchepov, A.V.; Radeloff, V.C.; Dubinin, M.; Alcantara, C. The effect of Landsat ETM/ETM image acquisition dates on the detection of agricultural land abandonment in Eastern Europe. Remote Sens. Environ. 2012, 126, 195-209. [CrossRef]

40. Baumann, M.; Kuemmerle, T.; Elbakidze, M.; Ozdogan, M.; Radeloff, V.C.; Keuler, N.S.; Prishchepov, A.V.; Kruhlov, I.; Hostert, P. Patterns and drivers of post-socialist farmland abandonment in Western Ukraine. Land Use Policy 2011, 28, 552-562. [CrossRef]

41. Szostak, M.; Hawryło, P.; Piela, D. Using of Sentinel-2 images for automation of the forest succession detection. Eur. J. Remote Sens. 2017, 51, 142-149. [CrossRef]

42. Kanjir, U.; Đurić, N.; Veljanovski, T. Sentinel-2 Based Temporal Detection of Agricultural Land Use Anomalies in Support of Common Agricultural Policy Monitoring. ISPRS Int. J. Geo-Inf. 2018, 7, 405. [CrossRef]

43. Proisy, C.; Viennois, G.; Sidik, F.; Andayani, A.; Enright, J.A.; Guitet, S.; Gusmawati, N.; Lemonnier, H.; Muthusankar, G.; Olagoke, A.; et al. Monitoring mangrove forests after aquaculture abandonment using time series of very high spatial resolution satellite images: A case study from the Perancak estuary, Bali, Indonesia. Mar. Pollut. Bull. 2018, 131, 61-71. [CrossRef] [PubMed]

44. Noi, P.T.; Kappas, M. Comparison of Random Forest, k-Nearest Neighbor, and Support Vector Machine Classifiers for Land Cover Classification Using Sentinel-2 Imagery. Sensors 2017, 18, 18.

45. Maxwell, A.E.; Warner, T.A.; Fand, F. Implementation of machine-learning classification in remote sensing: An applied review. Int. J. Remote Sens. 2018, 39, 2784-2817. [CrossRef]

46. Viñals, M.J. Secuencias Estratigráficas y Evolución Morfológica del Extremo Meridional del Golfo de Valencia (Cullera-Dénia). El Cuaternario del País Valenciano, 1st ed.; Universitat de València-AEQUA: Valencia, Spain, 1995.

47. Viñals, M.J. El Marjal de Oliva-Pego: Geomorfología y Evolución de un Humedal Costero Mediterráneo, 1st ed.; Conselleria de Agricultura y Medio Ambiente, Generalitat Valenciana: Valencia, Spain, 1996.

48. R Core Team. R: A Language and Environment for Statistical Computing; R Core Team: Viena, Austria, 2019.

49. Hijmans, R.J. raster: Geographic Data Analysis and Modeling, R package version 3.1-5; 2020. Available online: https://rdrr.io/cran/raster/ (accessed on 20 June 2020).

50. Bivard, R.; Keitt, T.; Rowlingson, B. rgdal: Bindings for the 'Geospatial' Data Abstraction Library, R package version 1.5-8; 2020. Available online: https://cran.r-project.org/web/packages/rgdal/index.html (accessed on 20 June 2020).

51. Richter, R.; Louis, J.; Müller-Wilm, U. Sentinel-2 MSI-Level 2A products algorithm theoretical basis document. Eur. Space Agency 2012, 49, 1-72.

52. Huete, A.; Justice, C.; Liu, H. Development of vegetation and soil indices for MODIS-EOS. Remote Sens. Environ. 1994, 49, 224-234. [CrossRef]

53. Thiam, A.K. Geographic Information Systems and Remote Sensing Methods for Assessing and Monitoring Land Degradation in the Sahel Region: The Case of Southern Mauritania. ProQuest Dissertations and Theses. Ph.D. Thesis, Clark University, Worcester, MA, USA, 1998.

54. Wilson, E.H.; Shader, S.A. Detection of forest harvest type using multiple dates of Landsat TM imagery. Remote Sens. Environ. 2002, 80, 385-396. [CrossRef]

55. Silleos, N.G.; Alexandridis, T.K.; Gitas, I.Z.; Perakis, K. Vegetation Indices: Advances Made in Biomass Estimation and Vegetation Monitoring in the Last 30 Years. Geocarto Int. 2006, 21, 21-28. [CrossRef] 
56. Huete, A.; Justice, C.; Van Leeuwen, W. MODIS vegetation index (MOD13). Algorithm Theor. Basis Doc. 1999, 3, 1-129.

57. Huete, A. A soil-adjusted vegetation index (SAVI). Remote Sens. Environ. 1988, 25, 295-309. [CrossRef]

58. Gitelson, A.A.; Kaufman, Y.J.; Merzlyak, M.N. Use of a green channel in remote sensing of global vegetation from EOS-MODIS. Remote Sens. Environ. 1996, 58, 289-298. [CrossRef]

59. Breiman, L. Random Forests-Random Features; Technical Report 567; Statistics Department, University of California: Berkeley, CA, USA, 1999.

60. Breiman, L. Random Forests. Mach. Learn. 2001, 45, 5-32. [CrossRef]

61. Breiman, L.; Friedman, J.H.; Olshen, R.A.; Stone, C.J. Classification and Regression Trees, 1st ed.; Wadsworth: Monterey, CA, USA, 1984.

62. Gislason, P.O.; Benediktsson, J.A.; Sveinsson, R.J. Random Forests for land cover classification. Pattern Recognit. Lett. 2006, 27, 294-300. [CrossRef]

63. Breiman, L. Bagging predictors. Mach. Learn. 1996, 24, 123-140. [CrossRef]

64. Pal, M. Random forest classifier for remote sensing classification. Int. J. Remote Sens. 2005, 26, $217-222$. [CrossRef]

65. Liaw, A.; Wiener, M. Classification and regression by randomForest. $R$ News 2002, 2, 18-22.

66. Kuhn, M.; Cont. Caret: Classification and Regression Training, R package version 6.0-84; 2019; Available online: https://cran.r-project.org/web/packages/caret/caret.pdf (accessed on 20 June 2020).

67. Congalton, R.G.; Green, K. Assessing the Accuracy of Remotely Sensed Data, 3rd ed.; CRC Press: Boca Raton, FL, USA, 2019.

68. Radoux, J.; Bogaert, P.; Defourny, P. Overall accuracy estimation for geographic object-based image classification. In Proceedings of the Ninth International Symposium on Spatial Accuracy Assessment in Natural Resources and Environmental Sciences, Leicester, UK, 20-23 July 2010.

69. Hernando, A.; Tiede, D.; Albrecht, F.T.; Lang, S. Novel parameters for evaluating the spatial and thematic accuracy of land cover maps, International Conference on Geographic Object-Based Image Analysis. In Proceedings of the International Conference on Geographic Object-Based Image Analysis, 4.(GEOBIA), Rio de Janeiro, Brazil, 7-9 May 2012.

70. Olofson, P.; Foody, G.M.; Herold, M.; Stehman, S.V.; Woodcock, C.E.; Wulder, M.A. Good practices for estimating area and assessing accuracy of land change. Remote Sens. Environ. 2014, 148, 42-57. [CrossRef]

71. Whiteside, T.G.; Maier, S.W.; Boggs, G.S. Area-based and location-based validation of classified image objects. Int. J. Appl. Earth Obs. Geoinf. 2014, 5, 117-130. [CrossRef]

72. Morell-Monzo, S.; Membrado-Tena, J.C. Causas y consecuencias del crecimiento urbanístico del litoral valenciano a través de la evolución de los usos del suelo. El caso de Oliva. Cuad. Tur. 2020, 44, 303-326. [CrossRef]

73. Yang, Z.; Mueller, R. Heterogeneously sensed imagery radiometric response normalization for citrus grove change detection. In Optics for Natural Resources, Agriculture, and Foods; SPIE: Washington, DC, USA, 2007.

74. Smith, P.; House, J.I.; Bustamante, M.; Sobocka, J.; Harper, R.; Pan, G.; West, P.C.; Clark, J.M.; Adhya, T.; Rumpel, C.; et al. Global change pressures on soils from land use and land management. Glob. Chang. Biol. 2016, 22, 1008-1028. [CrossRef]

(C) 2020 by the authors. Licensee MDPI, Basel, Switzerland. This article is an open access article distributed under the terms and conditions of the Creative Commons Attribution (CC BY) license (http://creativecommons.org/licenses/by/4.0/). 